\title{
Pelaksanaan Sistem Penyimpanan Rekam Medis Family Folder di Puskesmas Bayan Lombok Utara
}

\author{
Eka Mardyawati ${ }^{1}$, Akhmadi ${ }^{2}$ \\ Program Studi Diploma III Rekam Medis SV UGM ${ }^{1}$, Bagian Ilmu Keperawatan FK UGM ${ }^{2}$ \\ Eka.mardyawati@mail.ugm.ac.id ${ }^{1}$, Akhmadiugm@gmail.com²
}

\begin{abstract}
ABSTRAK
Latar Belakang: Ketersediaan berkas secara cepat dan tepat pada saat dibutuhkan akan sangat membantu mutu pelayanan kesehatan yang diberikan kepada pasien. Pelaksanaan pengambilan berkas rekam medis pasien di Puskesmas Bayan Lombok Utara tidak menggunakan tracer mengakibatkan berkas rekam medis sulit ditemukan serta berkas rekam medis disimpan tidak rapi sehingga sering terjadi berkas yang tidak ditemukan (missfile).

Tujuan: Mengetahui bagaimana pelaksanaan sistem penyimpanan rekam medis family folder di Puskesmas Bayan Lombok Utara.

Metode: Jenis penelitian yang digunakan adalah penelitian deskriptif dengan pendekatan kualitataif dan rancangan fenomenologis. Pengambilan data dengan wawancara, observasi dan studi dokumentasi. Subyek penelitian yang digunakan pada penelitian ini adalah seluruh petugas rekam medis di Puskesmas Bayan Lombok Utara.

Hasil: Pengambilan dan pengembalian rekam medis tidak menggunakan tracer, lokasi penyimpanan rekam medis tersentralisasi dengan sistem penyimpanan family folder. Belum terdapat prosedut tetap yang mengatur pelaksanaan sistem penyimpanan. Terdapat lima orang petugas penyimpanan rekam medis dan belum pernah mengikuti pelatihan serta bukan termasuk lulusan rekam medis. Map belum terdapat kolom untuk tempat menuliskan tahun kunjungan terakhir pasien melakukan pemeriksaan atau berobat. Map juga mudah sobek dan bentuk map tidak mempermudah petugas dalam pencarian berkas rekam medis. Rak penyimpanan berkas rekam medis di Puskesmas Bayan Lombok Utara berbentuk seperti rak sortir, sehingga dalam hal ini tidak sesuai dengan bentuk rak penyimpanan rekam medis pada umumnya. Hambatan yang ditemukan diantaranya pencarian berkas rekam medis lama, nomor rekam medis ganda, berkas rekam medis tidak ditemukan, dan kurangnya rak penyimpanan.
\end{abstract}

Kata Kunci: Evaluasi, pelaksanaan, sistem penyimpanan, family folder

\begin{abstract}
Background: Availability of files by quickly and accurately when needed will help the quality of health care was provided to patients. Implementation of retrieval the patients medical record in Puskesmas Bayan Lombok Utara not using tracer causes medical record difficult to find and not neat become medical record was not found (missfile).

Objective: To examine how implementation filing systems for medical record with family folder in Puskesmas Bayan Lombok Utara.

Methods: The research was conducted using a descriptive qualitative reseach with phenomenological design. Data collection techniques was using interviews, observation and documentation study.

Result: Implementation of the retrieval and filing system of medical records was not using tracer, based on location ofmedical record filing was using a centralization system and filing system of medical record was family folder. Haven't procedure of the implementation of filing systems. There are five officers responsible for the filing of medical records, the five officers have not been trained medical record training and not including graduate of medical records. Medical record folder in Puskesmas Bayan Lombok Utara has not found a place to write a column for the last visit of examination or treatment. Medical record folder are also easy to ripped and form of medical record folder does not help officers looking for medical record. Filing of medical record shaped like a sorting rack. So, in this case, does not same with the shape of the medical record filing generally. There are several barrier in the implementation of family folder system of medical records of filing system include looking for old medical record, duplicate medical record number, medical record file is not found, and less of filing shelves

Keywords: evaluation, implementation, filing systems, family folder
\end{abstract}




\section{PENDAHULUAN}

Puskesmas merupakan fasilitas pelayanan kesehatan tingkat pertama yang dapat membantu mewujudkan derajat kesehatan yang optimal serta memiliki peran penting dalam pelaksanaan rekam medis (Kepmenkes RI, 2009). Rekam medis memiliki arti yang cukup luas, tidak hanya terbatas berkas yang digunakan untuk menuliskan data pasien tapi juga dapat berupa rekaman dalam bentuk sistem informasi yang dapat digunakan untuk mengumpulkan segala informasi pasien terkait pelayanan yang diberikan di fasilitas pelayanan kesehatan sehingga dapat digunakan untuk berbagai kepentingan, seperti pengambilan keputusan pengobatan kepada pasien, bukti legal pelayanan yang telah diberikan, dan dapat juga sebagai bukti tentang kinerja sumber daya manusia di fasilitas pelayanan kesehatan (Huffman,1994).

Ketersediaan berkas secara cepat dan tepat pada saat dibutuhkan akan sangat membantu mutu pelayanan kesehatan yang diberikan kepada pasien. Berkas rekam medis pasien lama sulit di temukan sehingga proses pencarian berkas rekam medis pasien di rak penyimpanan membutuhkan waktu yang cukup lama, terjadi duplikasi nomor rekam medis pasien. Sistem penyimpanan berkas rekam medis pasien di Puskesmas Bayan Lombok Utara tidak menggunakan tracer, terdapat ketidakrapian urutan penyimpanan berkas rekam medis sehingga sering terjadi berkas yang tidak ditemukan (missfile). Walaupun di Puskesmas Bayan Lombok Utara menggunakan sistem family folder dalam penyimpanan berkas rekam medisnya namun dimasing-masing formulir belum diberi tambahan kode khusus untuk menandai kode rekam medis ayah, ibu, dan anak.

Tujuan dari penelitian ini adalah mengetahui bagaimana pelaksanaan sistem penyimpanan rekam medis family folder di Puskesmas Bayan Lombok Utara, yakni dengan mengetahui pelaksanaan sistem penyimpanan rekam medis di Puskesmas Bayan Lombok Utara dilihat dari pelaksanaan pengambilan dan pengembalian rekam medis pasien, sistem penyimpanan, prosedur sistem penyimpanan, sumber daya manusia, serta sarana dan prasarana penyimpanan. Selain itu juga mengetahui masalah yang dihadapi dalam pelaksanaan sistem penyimpanan rekam medis family folder di Puskesmas Bayan Lombok Utara

\section{METODE}

Jenis penelitian yang digunakan adalah penelitian deskriptif dengan pendekatan kualitatif dan rancangan fenomenologis.

Subyek penelitian yang digunakan pada penelitian ini adalah seluruh petugas rekam medis, terdiri dari satu Kepala Sub Bagian Tata Usaha dan lima petugas loket (pendaftaran pasien rawat jalan dan penyimpanan rekam medis) Puskesmas Bayan Lombok Utara.

Obyek yang digunakan dalam penelitian ini adalah tempat penyimpanan rekam medis dan seluruh berkas rekam medis pasien lama rawat jalan yang berkunjung ke Puskesmas Bayan Lombok Utara selama penelitian dilakukan pada bulan Februari sampai dengan bulan Maret 2016 berjumlah 260 berkas rekam medis pasien lama rawat jalan.

Teknik pengumpulan data yang digunakan dalam penelitian ini adalah wawancara, observasi dan studi dokumentasi. Dalam penelitian ini peneliti melakukan wawancara dengan Kepala Sub Bagian Tata Usaha dan lima orang petugas loket (petugas pendaftaran pasien rawat jalan) yang bertanggung jawab dengan penyimpanan berkas rekam medis. Observasi yang dilakukan berdasarkan atas pengalaman langsung yaitu mengamati ruang penyimpanan berkas rekam medis di Puskesmas Bayan Lombok Utara. Teknik pengumpulan data dengan studi dokumentasi pada penelitian ini dilakukan dengan cara melihat prosedur tetap pelaksanaan rekam medis di Puskesmas Bayan Lombok Utara terutama prosedur tetap tentang sistem penyimpanan rekam medis.

Instrumen yang digunakan dalam penelitian ini antara lain

1. Panduan wawancara

Merupakan daftar pertanyaan yang telah dibuat oleh peneliti sebelum melakukan penelitian. Dalam penelitian ini peneliti mengajukan pertanyaan sebanyak enam 
belas pertanyaan yang di ajukan kepada Kepala Sub Tata Usaha Puskesmas Bayan Lombok Utara dan lima orang petugas loket (petugas pendaftaran pasien rawat jalan) Puskesamas Bayan Lombok Utara.

2. Ceklis observasi

Merupakan panduan berupa check list dalam mengamati suatu hal yang terjadi dilapangan dalam melakukan suatu penelitian. Dalam penelitian ini terdapat lima belas item yang peneliti amati terkait pelaksanaan sistem penyimpanan rekam medis famliy folder di Puskesmas Bayan Lombok Utara.

3. Ceklis studi dokumentasi

Panduan yang digunakan untuk mengumpulkan data yang diperoleh dari prosedur tetap, buku maupun dokumen lain yang berkaitan dengan pelaksanaan sistem penyimpanan rekam medis famliy folder di Puskesmas Bayan Lombok Utara. 4. Alat-alat yang digunakan untuk mendukung instrument pengumpulan data adalah kamera dan alat tulis untuk mencatat.

Analisis data dalam penelitian ini meliputi reduksi data, penyajian data, dan penarikan kesimpulan dan verifikasi. Reduksi data dalam penelitian ini adalah dengan memilah hasil wawancara, observasi dan studi dokumentasi. Penyajian data pada penelitian ini yaitu data disajikan dalam bentuk teks, gambar, tabel, dan grafik. Kesimpulan yang diperoleh dari penelitian ini adalah pelaksanaan pengambilan dan pengembalian berkas rekam medis family folder, sistem yang berkaitan dengan penyimpanan rekam medis, prosedur sistem penyimpanan rekam medis, petugas yang bertanggungjawab terhadap penyimpanan rekam medis, sarana dan prasarana yang mendukung penyimpanan rekam medis serta hambatan-hambatan pelaksanaan sistem penyimpanan rekam medis family folder.

\section{HASIL DAN PEMBAHASAN}

1. Pelaksanaan pengambilan dan pengembalian berkas rekam medis family folder di Puskesmas Bayan Lombok Utara. Di Puskesmas Bayan Lombok Utara dalam pelaksanaan pengambilan berkas rekam medis pasien tidak memanfaatkan trecer. Trecer merupakan alat petunjuk keluar jika dokumen rekam medis diambil atau dipinjam untuk digunakan pihak pasien atau petugas kesehatan didalam pelayanan kesehatan. Di Puskesmas Bayan Lombok Utara, proses pengambilan berkas rekam medis pasien dilakukan dengan cara melihat nomor rekam medis, nama kepala keluarga dan alamat dari pasien yang tertera di KIB (Kartu Identitas Berobat). Dengan tidak digunakannya trecer sebagai penanda berkas rekam medis pasien keluar dari rak penyimpanan, hal ini mengakibatkan terjadinya missfile berkas rekam medis di Puskesmas Bayan Lombok Utara. Missfile merupakan kondisi dimana berkas rekam medis tidak berada pada rak penyimpanan berkas rekam medis yang seharusnya. Menurut Depkes RI (1997) menyatakan bahwa tata cara pengambilan berkas rekam medis disebutkan bahwa setiap berkas rekam medis yang keluar dari ruang penyimpanan harus menggunakan petunjuk keluar atau biasa disebut tracer. Sehingga pelaksanaan pengambilan berkas rekam medis di Puskesmas Bayan Lombok Utara belum sesuai dengan Depkes RI (1997).

Berdasarkan hasil observasi dan wawancara, langkah-langkah pengembalian atau penyimpanan berkas rekam medis di Puskesmas Bayan Lombok Utara, antara lain:

a. Setelah berkas rekam medis kembali dari poliklinik atau UGD, berkas rekam medis akan dipilah dengan melihat nomor rekam medis, nama kepala keluarga, dan alamat yang tertera di formulir rawat jalan pasien.

b. Kemudian les (formulir rekam medis) pasien tersebut akan dimasukan ke dalam amplopnya.

c. Amplop (map berkas rekam medis) akan dikembalikan ke rak penyimpanan berkas rekam medis berdasarkan alamatnya. Namun dalam pelaksanaannya terdapat berkas rekam medis pasien yang disimpan secara tidak urut dan 
bukan pada tempatnya. Menurut Depkes RI (1997), prosedur dalam pengembailan berkas rekam medis rawat inap dan rawat jalan adalah:

a. Rekam medis pasien rawat jalan yang telah dilengkapi oleh dokter yang memeriksa harus segera dikirim ke unit rekam medis sebelum berakhirnya jam kerja.

b. Rekam medis rawat inap harus segera dikirim ke unit rekam media setelah pasien keluar rumah sakit paling lambat $2 \times 24$ jam setelah pasien keluar secara lengkap dan benar.

c. Berkas rekam medis yang belum lengkap dikembalikan keruang inap masing-masing untuk segera dilengkapi baik oleh dokter maupun perawat.

d. Rekam medis disimpan sebaik mungkin sehingga apabila diperlukan kembali dapat ditemukan dengan cepat.

e. Rekam medis tidak boleh diketahui atau dilihat oleh orang yang tidak berwenang serta tidak boleh keluar dari rumah sakit kecuali oleh permintaan pengadilan.

2. Sistem yang berkaitan dengan penyimpanan rekam medis di Puskesmas Bayan Lombok Utara

a. Sistem Penomoran

Penomoran family folderyang digunakan terdiri dari huruf dan angka. Huruf diawal merupakan huruf awal dari nama kepala keluarga dan angka diakhir merupakan angka berdasarkan nomor buku bantu di Puskesmas Bayan Lombok Utara. Pelaksanaan buku bantu atau KIUP di Puskesmas Bayan Lombok Utara belum sesuai berdasarkan Budi (2011). Menurut Budi (2011), MPI yaitu indeks yang berisi data pokok mengenai identitas pasien untuk mengidentifikasi semua pasien yang pernah berobat. Menurut DepKes RI (1997) penomoran keluarga (family folder) adalah catatan tentang kondisi kesehatan suatu keluarga, sebagai akibat adanya masalah kesehatan atau penyakit pada salah satu atau lebih dari anggota keluarganya. Menurut Huffman (1994), penomoran keluarga biasanya terdiri dari penggunaan sepasang angka extra yang menunjukan posisi seseorang di dalam keluarga. Di Puskesmas Bayan Lombok Utara penomoran family folder nya tidak menggunakan nomor extra.

b. Sistem pengolahan rekam medis

Pengolahan berkas rekam medis di Puskesmas Bayan Lombok Utara dilakukan secara sentralisasi. Berkas rekam medis pasien di Puskesmas Bayan Lombok Utara disimpan pada rak penyimpanan dan berkas rekam medis yang sama yang berada di loket penerimaan pasien rawat jalan. Menurut Budi (2011), Sistem penyimpanan berkas rekam medis secara sentralisasi yaitu suatu sistem penyimpanan dengan cara menyatukan berkas rekam medis pasien rawat jalan, rawat darurat, dan rawat inap kedalam satu folder tempat penyimpanan.

3. Prosedur sistem penyimpanan rekam medis Puskesmas Bayan Lombok Utara belum mempunyai prosedur tetap berkaitan dengan rekam medis terutama sistem penyimpanan.

Menurut Siagian (2009) dalam Budiman (2011), dari sudut pandang pengolahan data, prosedur kerja menentukan tata cara identifikasi sumber data, cara penyimpanan data, pengoprasian dan pemeliharaan perangkat keras, mengendalikan kualitas keluaran, pendistribusian informasi, cara perbaikan kesalahan, serta tatacara pemeliharaan keamanaan data dan informasi dalam arti jangan sampai jatuh ditangan orang atau pihak yang tidak berhak, kerusakan data dan kebakaran. Prosedur merupakan instrumen untuk menjamin bahwa keseluruhan proses pengolahan data disegerakan dengan baik dan sebagaimana mestinya. 
4. Petugas penyimpanan berkas reakam medis (Man atau Sumber Daya Manusia)

Puskesmas Bayan Lombok Utara terdapat lima orang petugas loket (penerimaan pasien rawat jalan) yang dibawahi oleh seorang kepala tata usaha. Pendidikan petugas di Puskesmas Bayan Lombok Utara tidak ada lulusan dari rekam medis, tetapi Kepala Sub Bagian Tata Usaha pernah mendapatkan pelatihan rekam medis selama satu minggu. Sedangkan petugas loket (penerimaan pasien rawat jalan) belum pernah mendapatkan pelatihan sama sekali.

Menurut PP RI Nomor 32 Tahun 1996, tentang tenaga kesehatan pasal 1 dan 3 perekam medis termasuk tenaga kesehatan (tenaga keteknisian medis) dan tenaga kesehatan wajib memiliki pengetahuan dan keterampilan di bidang kesehatan yang dinyatakan dengan ijazah-ijazah lembaga pendidikan. Menurut Nawawi (2008), salah satu usaha pengembangan sumber daya manusia yakni dengan pelatihan. Pelatihan adalah proses memberikan bantuan bagi para pekerja untuk menguasai keterampilan khusus atau membantu untuk memperbaiki kekurangannya

5. Sarana dan prasarana penyimpanan rekam medis di Puskesmas Bayan Lombok Utara

a. Folder atau Map family folder Map di Puskesmas Bayan Lombok Utara belum terdapat kolom untuk tempat menuliskan tahun kunjungan terakhir pasien melakukan pemeriksaan atau berobat di Puskesmas Bayan Lombok Utara. Bahan map juga tipis dan mudah sobek. Bentuk map tidak mempermudah dalam pencarian berkas rekam medis, sehingga kurang bisa melindungi dari bahaya kerusakan fisik. Menurut WHO (2006), map (folder) merupakan pelindung kertas yang terbuat dari karton, manila atau plastik. Semua formulir rekam medis harus disimpan dalam map.
Harus dengan map manila dan jika mungkin membeli map karton yang lebih kuat. Menurut WHO (2006), pada map (folder) berkas rekam medis harus terdapat nama lengkap pasien, nomor berkas rekam medis, tahun kunjungan terakhir.

b. Rak penyimpanan berkas rekam medis Puskesmas Bayan Lombok Utara memiliki tiga rak penyimpanan rekam medis satu muka dengan ukuran yang berbeda. Menurut Rustiyanto dan Rahayu (2011), bentuk penyimpanan secara manual selain menghabiskan ruangan, karena tidak bisa digerakan, bentuk penyimpanan ini juga dinilai kurang aman dari bahaya kebakaran, karena bahannya terbuat dari kayu, sehingga dokumen yang ada didalamnya jika ada kebakaran dengan sangat mudah ikut terbakar.

c. Petunjuk penyimpanan atau guide Puskesmas Bayan Lombok Utara dalam menandai nama setiap alamat berdasarkan nama desa dan nama dusunnya menggunakan kertas print berwarna putih, dengan tinta berwarna hitam, menggunakan huruf cetak atau kapital, dan di tempelkan pada bagian atas rak dan di rekatkan menggunakan isolasi bening. Guide merupakan petunjuk, tempat berkas-berkas itu disimpan sekaligus berfungsi sebagai pemisah antara berkas-berkas tersebut (Barthos, 2007). Menurut Huffman (1994) jumlah kebutuhan petunjuk penyimpanan bergantung pada ketebalan dari mayoritas berkas yang disimpan. Semakin tebal berkas, maka semakin banyak petunjuk penyimpanan yang diperlukan.

6. Hambatan-hambatan pelaksanaan sistem penyimpanan rekam medis family folder di Puskesmas Bayan Lombok Utara

a. Pencarian berkas rekam medis lama 
Tabel 4.

Prosentase jumlah berkas hasil analisis waktu pencarian berkas pasien rawat jalan di Puskesmas Bayan Lombok Utara

\begin{tabular}{rccc}
\hline No & Keterangan & $\begin{array}{c}\text { Jumlah Berkas } \\
\text { Rekam Medis }\end{array}$ & Persentase \\
\hline 10 menit & 124 & $63.59 \%$ \\
$>10$ menit & 71 & $36.41 \%$ \\
\hline Total & & $100 \%$ \\
\hline
\end{tabular}

Dapat diketahui bahwa presentase waktu pencarian berkas rekam medis di Puskesmas Bayan Lombok Utara 10 menit sebesar $63,59 \%$ dan > 10 menit sebesar $36.41 \%$. Dari hasil prosentase tersebut terdapat $36,41 \%$ berkas rekam medis yang membutuhkan waktu pencarian > 10 menit. Waktu pencarian berkas rekam medis > 10 menit biasanya dipengaruhioleh banyaknya jumlah pasien yang berkunjung dalam waktu bersamaan ditambah dengan pasien yang tidak sabaran dan ingin cepat dilayani, sehingga petugas mencari rekam medis dengan tergesa-gesa dan kurang teliti.

Menurut Antikasari (2006), pelayanan yang cepat kepada pasien tidak lepas dari kerjasama antara petugas di Puskesmas. Cepat tidaknya pelayanan medis pasien dipengaruhi penyediaan berkas rekam medis. Berdasarkan Kepmenkes RI Nomor 129/ Menkes/SK/II/2008 tentang Standar Pelayanan Minimal (SPM) rekam medis terkait dengan waktu penyediaan berkas yaitu untuk rawat jalan 10 menit.

b. Nomor rekam medis ganda

Di Puskesmas Bayan Lombok Utara, terdapat kasus pasien memiliki lebih dari satu nomor rekam medis, sehingga berkasnya juga lebih dari satu, dengan nomor yang berbeda. Menurut Permenkes Nomor 55 Tahun 2013 tentang Penyelenggaraan Pekerjaan Perekam Medis, rekam medis adalah berkas yang berisi catatan dan dokumen tentang identitas pasien, pemeriksaan, pengobatan, tindakan dan pelayanan lain kepada pasien pada fasilitas pelayanan kesehatan. Menurut Huffman (1994), rekam medis adalah rekaman atau catatan mengenai siapa, apa, mengapa, bilamana, dan bagaimana pelayanan yang diberikan kepada pasien selama masa perawatan, yang memuat pengetahuan mengenai pasien dan pelayanan yang diperoleh, serta memuat informasi yang cukup untuk mengidentifikasi, membenarkan diagnosis dan pengobatan, serta merekam hasilnya.

Berdasarkan Depkes RI (1997), tujuan rekam medis adalah menunjang tercapainya tertib administrasi dalam rangka upaya peningkatan pelayanan kesehatan. Menurut Depkes RI Dirjen Pelayanan Medis dalam buku Pedoman Pengolahan Rekam Medis Rumah Sakit di Indonesia, kegunaanya dapat dilihat dari beberapa aspek, antara lain:

1) Apek Administrasi

Suatu berkas rekam medis mempunyai nilai administrasi, karena isinya menyangkut tindakan berdasarkan wewenang dan tanggung jawab tenaga medis dan paramedis dalam mencapai tujuan pelayanan kesehatan.

2) Aspek Medis

Suatu berkas rekam medis mempunyai nilai medis, karena catatan tersebut dipergunakan sebagai dasar untuk merencanakan pengobatan/perawatan yang harus diberikan kepada pasien.

3) Aspek Hukum

Suatu berkas rekam medis mempunyai nilai hukum, karena isinya menyangkut masalah adanya jaminan kepastian hukum atas dasar keadilan dalam rangka usaha 
menegakan hukum serta penyediaan bahan tanda bukti untuk menegakan hukum.

\section{4) Aspek Keuangan}

Suatu berkas rekam medis mempunyai nilai keuangan, karena isinya mengandung data atau informasi yang dapat digunakan sebagai aspek keuangan.

5) Aspek Penelitian

Suatu berkas rekam medis mempunyai nilai penelitian, karena informasi yang dikandungnya dapat digunakan sebagai bahan penelitian dan pengembangan ilmu pengetahuan dibidang kesehatan.

6) Aspek Pendidikan

Kronologis dan kegiatan pelayanan medik yang diberikan kepada pasien, tersebut dapat dipergunakan sebagai bahan atau refrensi pengajaran dibidang profesi pengguna.

\section{7) Aspek Dokumentasi}

Suatu berkas rekam medis mempunyai nilai dokumentasi, karena isinya menyangkut sumber ingatan yang harus didokumentasikan dan dipakai sebagai bahan pertanggung jawaban laporan rumah sakit. Berdasarkan observasi, di PuskesmasBayan Lombok Utara terdapat nomor rekam medis ganda dimana pasien dengan identitas yang sama memiliki dua nomor rekam medis yang berbeda, sehingga data riwayat pemeriksaan pasien menjadi tidak berkesinambungan. Hal tersebut tidak sesuai dengan kegunaan rekam medis pada aspek medis dan aspek dokumentasi.

Berkas rekam medis tidak ditemukan dari observasi yang dilakukan oleh peneliti menunjukan bahwa rata-rata berkas yang tidak ditemukan setiap harinya adalah $5,42 \%$ dari rata-rata seluruh permintaan berkas setiap harinya $21,67 \%$. Prosentase berkas yang tidak dapat ditemukan adalah $25,00 \%$. Hal ini ditunjukan dalam tabel 5 .
Tabel 5.

Observasi pengambilan kembali berkas rekam medis Puskesmas Bayan Lombok Utara

\begin{tabular}{cccc}
\hline Tanggal & \multirow{2}{*}{$\begin{array}{c}\text { Jumlah } \\
\end{array}$} & $\begin{array}{c}\text { Pengam } \\
\text { bilan }\end{array}$ & \multicolumn{2}{c}{$\begin{array}{c}\text { Berkas Yang Tidak } \\
\text { Ditemukan }\end{array}$} \\
\cline { 3 - 4 } Berkas & Jumlah & Persentase \\
\hline $15 / 02 / 2016$ & 32 & 7 & $21.87 \%$ \\
$16 / 02 / 2016$ & 25 & 6 & $24.00 \%$ \\
$17 / 02 / 2016$ & 18 & 4 & $22.22 \%$ \\
$18 / 02 / 2016$ & 26 & 6 & $23.07 \%$ \\
$19 / 02 / 2016$ & 10 & 3 & $30.00 \%$ \\
$20 / 02 / 2016$ & 18 & 5 & $27.77 \%$ \\
$22 / 02 / 2016$ & 28 & 7 & $25.00 \%$ \\
$23 / 02 / 2016$ & 13 & 4 & $30.07 \%$ \\
$24 / 02 / 2016$ & 21 & 5 & $23.80 \%$ \\
$25 / 02 / 2016$ & 23 & 7 & $30.43 \%$ \\
$26 / 02 / 2016$ & 35 & 8 & $22.85 \%$ \\
$27 / 02 / 2016$ & 11 & 3 & $27.27 \%$ \\
\hline Total & 260 & 65 & $25.00 \%$ \\
\hline
\end{tabular}

Angka 3\% merupakan batas pataokan untuk menentukan baik buruknya suatu sistem penyimpanan berkas. Apabila angka kencermatan pempunyai prosentase lebih lebih dari itu, maka berkas yang bersangkutan adalah tidak efisien, sehingga perlu ditunjukan kembali sebab- sebabnya, mungkin sistem penyimpanan berkas yang digunakan perlu dirubah atau diperbaharui (Gie, 2009) dalam Umaera (2011).

c. Kurangnya rak penyimpanan

Puskesmas Bayan Lombok Utara memiliki tiga lemari terbuka untuk menyimpanan berkas rekam medis. Lemari terbuka tersebut digunakan untuk melindungi berkas rekam medis pasien dari kerusakan. Rak penyimpanan rekam medis yang di miliki Puskesmas Bayan Lombok Utara saat ini belum bisa menampung jumlah berkas rekam medis.

Menurut Rustiyanto dan Rahayu (2011), bentuk penyimpanan secara manual selain menghabiskan ruangan, karena tidak bisa digerakan, bentuk penyimpanan ini juga dinilai kurang aman dari bahaya kebakaran, karena bahannya terbuat daari kayu, sehingga dokumen yang ada didalamnya jika ada kebakaran dengan sangat mudah ikut terbakar. 


\section{PENUTUP}

A. Kesimpulan

1. Pelaksanaan pengambilan rekam medis di Puskesmas Bayan

Lombok Utara tidak menggunakan tracer. Dalam pelaksanaan pengembalian berkas rekam medis masih ada berkas rekam medis yang disimpan tidak sesuai pada tempatnya.

2. Ditinjau dari lokasi penyimpanan berkas rekam medis Puskesmas Bayan Lombok Utara menggunakan sistem sentralisasi dimana jenis penyimpanan rekam medisnya menggunakan sistem penyimpanan rekam medis family folder. Sistem penomoran family folder di Puskesmas Bayan Lombok Utara terdiri dari huruf dan angka, penomoran yang diberikan sesuai dengan nomor urut pasien di buku bantu ditambah dengan huruf awal dari nama kepala keluarga. Buku bantu di Puskesmas Bayan Lombok Utara merupakan nama lain dari Kartu Indeks Utama Pasien (KIUP). Bentuk KIUP dan pelaksanaan pembuatan KIUP tidak sesuai dengan teori. Penomoran family folder di Puskesmas Bayan Lombok Utara tidak terdapat kode wilayah dan tidak menggunakan angka extra, sampul atau map hanya terdapat nomor indeks keluarga saja.

3. Di Puskesmas Bayan Lombok Utara belum terdapat prosedur tetap tertulis yang mengatur tentang sistem penyimpanan rekam medis.

4. Di Puskesmas Bayan Lombok Utara, petugas yang bertanggung jawab terhadap penyimpanan rekam medis berjumlah lima orang petugas loket (petugas pendaftaran pasien rawat jalan) dan seorang Kepala Sub Bagian Tata Usaha. Seluruh petugas bukan termasuk lulusan rekam medis dan kelima petugas loket (petugas pendaftaran pasien rawat jalan) belum pernah mengikuti pelatihan rekam medis.

5. Ditinjau dari penggunaan folder atau map family folder, map di
Puskesmas Bayan Lombok Utara belum terdapat kolom untuk tempat menuliskan tahun kunjungan terakhir pasien melakukan pemeriksaan atau berobat di Puskesmas Bayan Lombok Utara. Bahan map juga tipis dan mudah sobek. Bentuk map tidak mempermudah dalam pencarian berkas rekam medis. Bentuk rak penyimpanan berkas rekam medis di Puskesmas Bayan Lombok Utara berbentuk seperti rak sortir, sehingga dalam hal ini tidak sesuai dengan bentuk rak penyimpanan rekam medis pada umumnya.

6. Dalam kegiatan filing terdapat beberapa masalah yang dapat menghambat pelayanan terhadap pasien, diantaranya:

a. Pencarian berkas rekam medis lama

b. Nomor rekam medis ganda

c. Berkas rekam medis tidak ditemukan

d. Kurangnya rak penyimpanan

B. Saran

1. Sebaiknya perlu dibuat prosedur tetap tertulis mengenai pelaksanaan pengambilan dan pengembalian rekam medis serta kebijakan tertulis mengenai sistem penyimpanan yang digunakan.

2. Sebaiknya dilakukan perbaikan pelaksanaan pembuatan Kartu Indeks Utama Pasien (KIUP).

3. Sebaiknya dilakukan perancangan ulang desain rak penyimpanan dan penambahan rak penyimpanan rekam medis.

4. Sebaiknya sistem penyusunan dokumen rekam medis menggunakan sistem penjajaran tidak seperti saat ini penyusunan dokumen rekam medis dengan cara ditumpuk.

5. Sebaiknya dilakukan perancangan ulang desain map rekam medis baru dan pengadaan kode warna, sehingga dapat memudahkan petugas dalam pencarian rekam medis. 
6. Sebaiknya dilakukan pelatihan untuk petugas rekam medis sehingga petugas rekam medis dapat meningkatkan ilmu pengetahuan dan kompetensi tentang rekam medis.

\section{DAFTAR PUSTAKA}

Budi, Savitri C. (2011). Manajemen Unit Kerja Rekam Medis. Yogyakarta: Quantum Sinergis Media.

Budiman. (2011). Pelaksanaan Sistem Penyimpanan Rekam Medis Personal Folder di Puskesmas Lendah II Kabupaten Kulon Progo. Karya Tulis Ilmiah (Tidak Dipublikasikan). Yogyakarta: Prodi D3 Rekam Medis.

Depkes RI. (1997). Pedoman Penyelenggaraan Rekam Medis Rumah Sakit Indonesia. www.depkes.go.id. pada tanggal 15 Desember 2015.

Depkes RI. (2008). Keputusan Menteri Kesehatan Republik Indonesia Nomor 129/Menkes/SK/II/2008 tentang Standar Pelayanan Minimal Rumah Sakit. WwW.depkes.go.id. pada tanggal 12 April 2016.

Depkes RI. (2009). Peraturan Menteri Kesehatan Republik Indonesia Nomor 875/Menkes/SK/IX/2009 tentang Pedoman Penilaian Kinerja Sumber Daya Manusia Kesehatan di Puskesmas. Www.depkes.go.id. pada tanggal 12 Desember 2015.

Huffman, E. K. (1994). Health Information Management. Physician Record. Company.Illinois.

Menkes RI. (2013). Peraturan Menteri Kesehatan Republik Indonesia Nomor 55 Tahun 2013 tentang Penyelenggaraan Perekam Medis. wWW.depkes.go.id. pada tanggal 30 Desember 2015.

Presiden RI. (1996). Peraturan Pemerintah Republik Indonesia Nomor 32 Tahun 1996 tentang Tenaga Kesehatan. wWw.depkes.go.id. pada tanggal 15 Maret 2015.

Rustiyanto, E. dan Rahayu, W.A. (2011). Manajemen Filing Dokumen Rekam Medis dan Informasi Kesehatan.
Yogyakarta: Politeknik Kesehatan Permata Indonesia.

Umaera. (2011). Tinjauan Pelaksanaan Sistem Penyimpanan Berkas Rekam Medis Rawat Jalan di RSUD Kabupaten Kebumen. Karya Tulis Ilmiah (Tidak Dipublikasikan). Yogyakarta: Prodi D3 Rekam Medis.

WHO. (2006). Medical Record Manual: A Guide for Developing Countries Geneva: WHO. www.wpro.who.int/publications/doc s/MedicalRecordManual.pdf. pada tanggal 25 Maret 2016 